\title{
Lack of association of cytomegalovirus with adenocarcinoma of the colon
}

\author{
HELENA HART, W A NEILL, AND MARY NORVAL* \\ From the Department of Bacteriology, University of Edinburgh Medical School, Edinburgh
}

SUMMARY Tumour specimens from patients with adenocarcinoma of the colon or rectum were examined for the presence of cytomegalovirus (CMV), and specimens of normal mucosa from the same patients were studied in parallel. Frozen sections of 14 specimens were made and the presence of CMV mRNA assayed by in situ hybridisation using ${ }^{3} \mathrm{H}$-labelled CMV-DNA as a probe. Nine of these sections were also tested for cytomegalovirus antigens by immunofluorescence. No viral nucleic acids or antigens were detected. In addition to these direct approaches, the specimens were disaggregated and 19 were successfully cultured in various media over several months without yielding virus on any occasion. Areas containing epithelial cells were found in some cultures, foci of bipolar cells in othess, while, in several, fibroblastic cells predominated. To ensure that any virus-containing cells were not lost by this method, the disaggregated tumour and normal intestinal cells were directly co-cultivated and also fused with human embryo lung cells, which are permissive for cytomegalovirus replication. The resulting cultures were examined over two to three months for the presence of cytomegalovirus, and in no instance was virus found, despite attempted induction by iododeoxyuridine. Two fusion cultures became contaminated with cytomegalovirus, strain AD-169, which was being handled in the laboratory at the same time. The strain was identified by the pattern of viral DNA fragments produced by restriction endonuclease cleavage. Thus the accidental passage of virus in the heterokaryons did not alter its DNA and would further indicate the absence of any cytomegalovirus genomes in the adenocarcinoma cells.

Two groups have presented evidence recently that cytomegalovirus may be involved in adenocarcinoma of the colon. In the first place, colonic tissues from seven adenocarcinoma cases were analysed by cRNA-DNA hybridisation and over $50 \%$ contained more than two genome equivalents/cell. ${ }^{1}$ Most control tissue obtained from normal colon and cases of Crohn's disease was negative. Secondly, several cases of adenocarcinoma of the colon were investigated by long-term culture of the tumour fragments. ${ }^{2}$ Eight cell lines grew out, consisting mainly of fibroblastic cells, and cytomegalovirus was isolated from three of these. It was identified by electron microscopy, cytology of infected cells, and by immunofluorescence.

In both these situations, it is not known whether cytomegalovirus might be the aetiological agent or is

\footnotetext{
*Address for correspondence: Dr M Norval, Department of Bacteriology, University of Edinburgh Medical School, Teviot Place, Edinburgh EH8 9AG.

Received for publication 21 May 1981
}

merely reactivated from a latent state. It is of interest in this context that cytomegalovirus has been found in the gastrointestinal tract, and is claimed to be associated with chronic or debilitating diseases such as ulcerative colitis or intestinal ulcers. ${ }^{3}$ Cytomegalovirus was isolated from three out of six cases of ulcerative colitis, and one out of four cases of regional enteritis by tissue culture. ${ }^{4}$ In addition, cytomegalovirus inclusions were reported in macrophages and fibroblasts located in granulation tissues at the base of deep ulcerations in the colon and ileum and within endothelial cells in several cases of ulcerative colitis. ${ }^{5}$ On the other hand, no virus was found after culture of cells from patients with Crohn's disease. ${ }^{6}$

Here we report our attempts to analyse further the association of cytomegalovirus with colon adenocarcinoma cells. In the first place, the results of cultuing the tumour cells from 19 patients are given, also the results of co-cultivating and fusing these with human embryo lung cells which are permissive for human cytomegalovirus replication. The heterokaryons 
produced from the fusions were treated with iododeoxyuridine to overcome the cellular control which might operate in such a situation. ${ }^{7}$ The presence of cytomegalovirus was assayed by the observation of cytopathic effect and labelling with ${ }^{3} \mathrm{H}$-thymidine. The cytomegalovirus isolates obtained were characterised by analysis of fragments produced by the restriction endonucleases EcoRI, BgI II, and Hind III.

Secondly, 14 adenocarcinoma specimens were examined directly, as frozen sections, for cytomegalovirus antigens using immunofluorescence and for cytomegalovirus nucleic acids by in situ hybridisation. In no case was any evidence of cytomegalovirus found.

\section{Methods}

CLINICAL SPECIMENS

Surgically resected specimens of colon or rectum were obtained from the Royal Infirmary, Edinburgh, within a few minutes of being removed from the patient. Control specimens included pieces of normal colonic wall from the same patient, and others with Crohn's disease, ulcerative colitis, and diverticular disease. They underwent routine pathological examination, the diagnosis being based on this result. As soon as possible, and generally within two hours of the operation, small pieces of tumour (about $3 \mathrm{~mm}^{3}$ ) and part of the normal colon were frozen by dropping into liquid nitrogen and were subsequently used to prepare $5 \mu \mathrm{m}$-thick frozen sections. These were stored at $-20^{\circ} \mathrm{C}$ until required for immunofluorescence and in situ hybridisation studies. In addition, for culturing, similar small pieces were removed, finely minced and treated for one hour at $37^{\circ} \mathrm{C}$ in Earle's salt-based Eagle's medium containing $100 \mathrm{IU} / \mathrm{ml}$ gentamicin, 100 $\mathrm{IU} / \mathrm{ml}$ mycostatin, $100 \mathrm{IU} / \mathrm{ml}$ penicillin, and 100 $\mu \mathrm{g} / \mathrm{ml}$ streptomycin. Soft tumours 'spilled out' cells during this time and these were used for culture, fusion, and co-cultivation experiments. Hard tumours and normal colon were digested with collagenase/dispase according to the manufacturer's instruction (Boehringer Mannheim) to obtain single cells.

The separated cells were used directly for culture in Eagle's medium containing antibiotics as above and supplemented with $10 \%$ fetal calf serum. They were seeded into Falcon flasks (Nunc) and observed for any morphological change over periods of two to three months. Latterly, a modification of this medium was used which contained D-valine. ${ }^{8}$

The disaggregated cells were also used for cocultivation experiments after mixing with an equal number of human embryo lung cells. They were examined over the next two to three months, being subcultured three or four times in this interval.

\section{CELLS}

Human embryo lung cells were obtained by trypsinising human fetal lungs and seeding the cells in Eagle's medium supplemented with $10 \%$ fetal calf serum and containing $100 \mathrm{IU} / \mathrm{ml}$ penicillin and $100 \mu \mathrm{g} / \mathrm{ml}$ streptomycin. Confluent fibroblastic monolayers were passed by trypsinisation and used between passage numbers 5-20, being grown in Eagle's medium with $5 \%$ newborn calf serum and being maintained in the same medium with $2 \%$ newborn calf serum. They were free of Mycoplasma contamination.

Two colon adenocarcinoma cell lines were obtained. HX18 line was kindly donated by Dr Courtenay who has described the growth and characteristics of these cells. ${ }^{9}$ The other line came from Dr L K Woods and Dr G E Moore and has been described elsewhere. ${ }^{10}$ Both cell lines grew in suspension, forming large clumps similar to those observed in fresh specimens of colon adenocarcinoma tumours. Both were grown in Eagle's medium with $10 \%$ fetal calf serum and antibiotics as for the human embryo lung cells above. They were contaminated with Mycoplasma species.

FUSION USING POLYETHYLENE GLYCOL Initially, 'spill out' cells from adenocarcinoma specimens and disaggregated cells from normal colon were used directly for fusion. Latterly, the tumour cells were separated from the other cell types and non-viable cells by gravity sedimentation through $10 \mathrm{ml}$ fetal calf serum for one hour at room temperature before fusion. The viable tumour cell clumps which formed were fused with human embryo lung cells using the method of Pontecorvo ${ }^{11}$, which was slightly modified as already described and illustrated. ${ }^{12}$ Various numbers of tumour and normal colonic cells were fused with $2 \times 10^{6}$ human embyro lung cells.

\section{STIMULATION OF VIRUS PRODUCTION BY IODODEOXYURIDINE}

Four weeks after the fusion, in the absence of a cytopathic effect, $20 \mu \mathrm{g} / \mathrm{ml}$ iododeoxyuridine (IUDR) was added to the medium for four days. It was then removed and the cultures observed as below for the presence of cytomegalovirus.

EXAMINATION OF CULTURES FOR THE

PRESENCE OF CYTOMEGALOVIRUS

Cultured, co-cultivated, and fused colonic cells were examined over two to three months in the following ways: (1) microscopically for changes to 
the cell sheet indicative of a cytopathic effect; (2) by labelling with $4 \mu \mathrm{Ci} / \mathrm{ml}{ }^{3} \mathrm{H}$-thymidine for 48 hours and analysing the concentrated culture supernatant by sucrose density centrifugation; ${ }^{13}$ (3) by anti-complement immunofluorescence ${ }^{14}$ (ACIF) with cytomegalovirus seropositive human sera at a dilution of 1/20 and human complement, seronegative for cytomegalovirus. Anti-human C3 fluorescein tagged conjugate (Hyland) was used at $1 / 20$ dilution.

The cytomegalovirus seropositive sera were tested by complement fixation and had titres of 2048. All contained antibodies to cytomegalovirus early and late antigens as judged by anti-complement immunofluorescence on human embryo lung cells infected with AD-169 two days post-infection and blocked with $40 \mu \mathrm{g} / \mathrm{ml}$ cytosine arabinoside (Sigma Chemical Company) (early), and on human embryo lung cells infected with AD-169 four days postinfection (late).

RESTRICTION ENDONUCLEASE ANALYSIS

OF CYTOMEGALOVIRUS ISOLATES

A modification of the method of Kilpatrick et al. ${ }^{15}$ and Huang (personal communication) was followed, using the DNA from infected cells rather than extracellular virus which may be difficult to obtain in large quantities from clinical isolates. Briefly, $4 \times 10^{6}$ human embryo lung cells which had been infected with cytomegalovirus were labelled with ${ }^{32} \mathbf{P}$ (as orthophosphate in aqueous solution, carrier free, The Radiochemical Centre, Amersham) at $\mathbf{4 0}$ $\mu \mathrm{Ci} / \mathrm{ml}$ in low phosphate medium, supplemented with $2 \%$ dialysed newborn calf serum. After three days, the labelled cells were washed twice with $0.01 \mathrm{M}$ Tris-HCl buffered saline $\mathrm{pH} 7 \cdot 4$, and digested with $1 \mathrm{mg} / \mathrm{ml}$ pronase (Boehringer Mannheim) and $1 \%$ sodium dodecyl sulphate in lysis buffer (0.05M Tris-HC1, 0.01M EDTA, pH 8.0) for four hours at $37^{\circ}$. DNA was extracted using water-saturated phenol, precipitated with ethanol, and redissolved in buffer. It was purified by caesium chloride equilibrium density centrifugation. Fractions of density $1.71-1.73 \mathrm{~g} / \mathrm{m}$ were pooled, dialysed overnight, precipitated with 2.5 volumes ethanol, and stored at $-20^{\circ} \mathrm{C}$ until required. Then they were redissolved in $50 \mu \mathrm{l}$ buffer containing $0.01 \mathrm{M}$ Tris-HC1, 0.001M EDTA, pH 7.4. Samples containing 10000 counts per minute were digested with restriction endonucleases EcoR l, Bgl II, and Hind III (Millipore UK Ltd) in appropriate digestion buffers for two hours at $37^{\circ} \mathrm{C}$. The restriction endonuclease fragments so produced were analysed on $1 \%$ agarose gels as described previously. ${ }^{15}$
IN SITU HYBRIDISATION

Cytomegalovirus DNA was prepared as already outlined. ${ }^{16}$ Briefly, human cytomegalovirus, strain AD169, was grown in human embryo lung cells and, after concentration by centrifugation of the culture supernatant, was purified by sucrose density gradient centrifugation. The band with density $1 \cdot 20-1 \cdot 23 \mathrm{~g} / \mathrm{ml}$ was collected and re-purified on a second sucrose gradient. Viral DNA was extracted using SDS and proteinase $\mathrm{K}$ followed by banding in a $10-40 \%$ sucrose gradient. Viral DNA was extracted twice with phenol and precipitated with ethanol. It was finally banded by $\mathrm{CsCl}$ equilibrium density centrifugation, and the fractions with density $1 \cdot 705-1 \cdot 725 \mathrm{~g} / \mathrm{ml}$ pooled, dialysed overnight, and the DNA precipitated with ethanol. The precipitate was dissolved finally in TES buffer $(0.05 \mathrm{M}$ Tris- $\mathrm{HCl}$, $0.15 \mathrm{M} \mathrm{NaCl}, 0.005 \mathrm{M}$ EDTA, pH 7.4) at a concentration of $50 \mu \mathrm{g} / \mathrm{ml}$.

Nick-translation was then carried out, ${ }^{17}$ the reaction mixture containing all four nucleotide triphosphates labelled with tritium (Amersham) and incubation continuing for five hours. $\mathrm{Cpm} / \mu \mathrm{g}$ nucleic acid after separation on a Sephadex G50 column was around $10^{7}$.

In situ hybridisation was carried out on frozen sections of colon which were fixed in ethanol: acetic acid, $3: 1$, for 10 minutes at $-20^{\circ} \mathrm{C}$ just before use, according to the method obtained from Rapp's laboratory.

\section{IMMUNOFLUORESCENCE}

The technique of amplified direct immunofluorescence (AMDI) as described by Schmitz and $\mathrm{Kampa}^{18}$ was used for the detection of cytomegalovirus antigens on frozen sections of tumour and normal colons. Two human sera were selected with antibodies to cytomegalovirus early antigens. Both had complement fixation titres of 1024 and, by ACIF, both stained only nuclei from cytomegalovirus-infected human embryo lung cells, one giving mainly a general nuclear staining and the other showing granular staining on early-infected nuclei. No non-specific antinuclear staining was present. These sera were labelled with fluorescein iso-thiocyanate, isomer I (FITC, Fluka 46952). ${ }^{19}$ For the AMDI test, the frozen sections were pre-incubated with human sera, negative for cytomegalovirus, at a dilution of $1 / 10$ for one hour at room temperature. This was followed by the FITC-labelled human sera at a dilution of $1 / 100$, then rabbit anti-FITC serum at a dilution of $1 / 160$, which had been kindly donated by Drs Schmitz and Kampa. Finally, anti-rabbit IgG labelled with FITC (Wellcome Laboratories) was used at $1 / 16$. 
Results

CULTURE OF TUMOUR CELLS

Cell cultures were set up from tumour specimens of 35 patients who were diagnosed histologically as having adenocarcinoma of the colon or rectum.

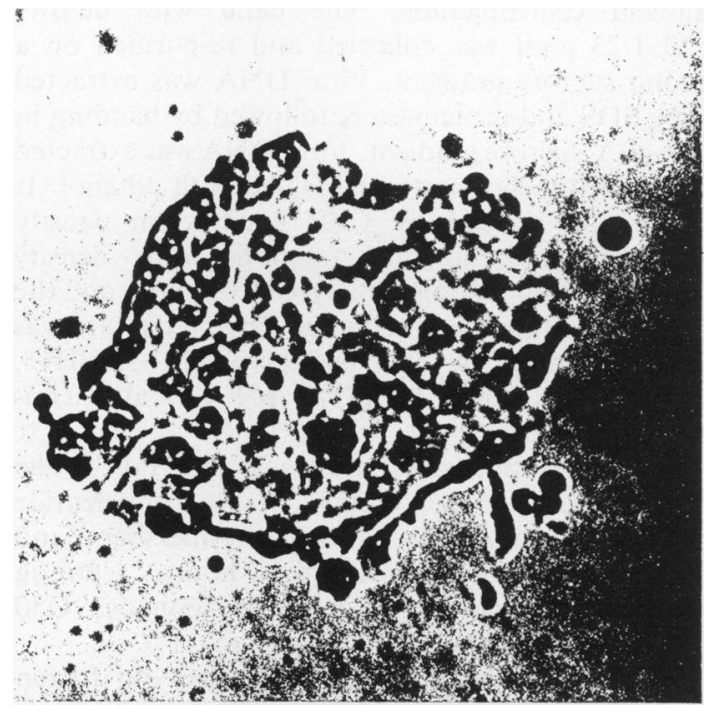

Fig. 1 Epithelial cells obtained on culture of colonic adenocarcinoma specimen. $x$ 211, phase contrast. (In this and the following figures original magnifications are given.)

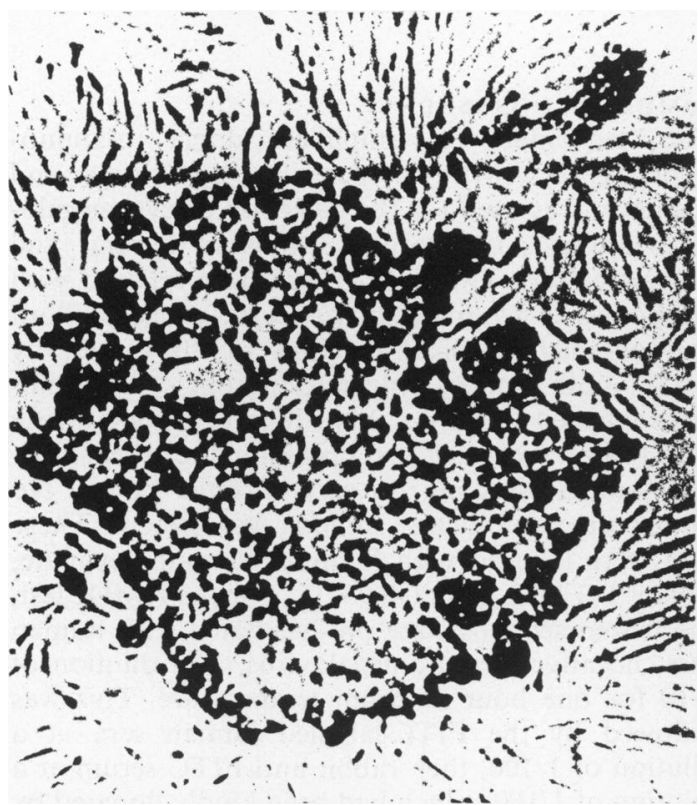

Fig. 2 Island of epithelial cells derived from colonic adenocarcinoma after co-cultivation with human embryo lung cells. $x 211$, phase contrast.
Cell growth was obtained in 19 of these. Areas of epithelial cells were observed in seven cultures, occasionally only when co-cultivated with human embryo lung cells. These are shown in Figs. 1 and 2. They appeared after two to three days in culture and persisted for two weeks to three months, dividing several times in this interval. However, attempts to subculture them were always unsuccessful, so that no lines of epithelial cells derived from adenocarcinomas have been established. The use of medium containing D-valine did not increase the number of epithelial cells obtained, promote their growth, or help maintain them on subculture.

Cultures containing discrete foci of bipolar cells, which have been described by Leibovitz et al, ${ }^{20}$ were sometimes seen and are demonstrated in Fig. 3. These cells also failed to grow on subculture.

Cells with characteristic fibroblastic morphology grew out from seven specimens and are shown in Fig. 4. These could be successfully subcultured at

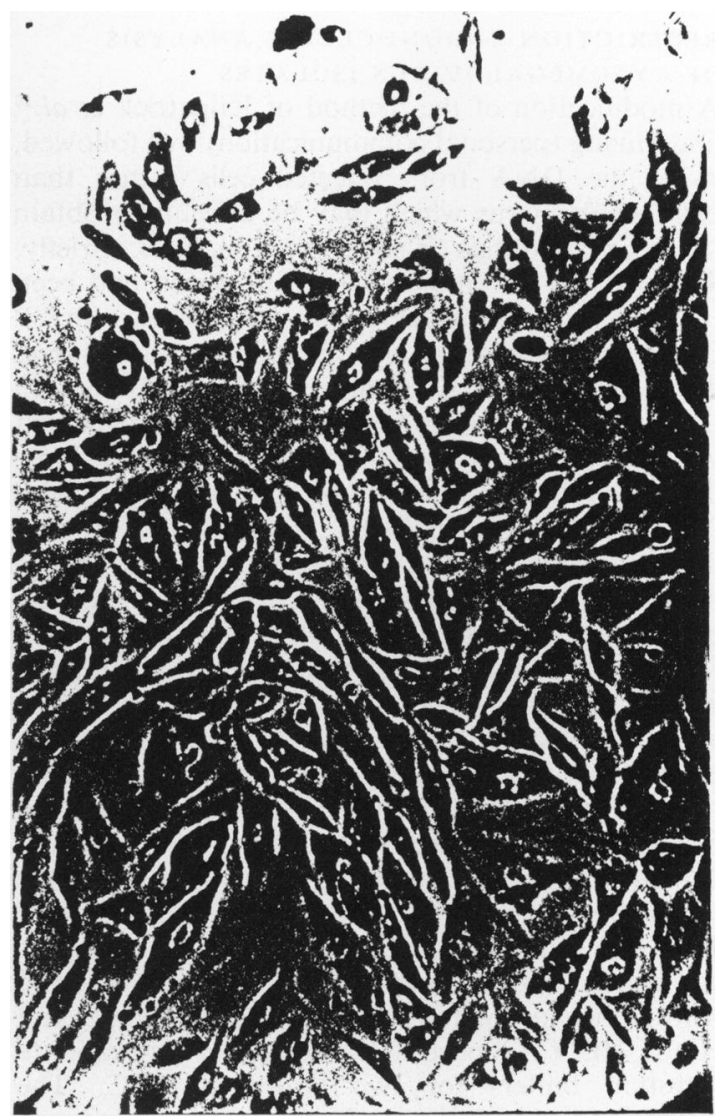

Fig. 3 Bipolar cells obtained on culture of colonic adenocarcinoma specimen. $x 825$, phase contrast. 


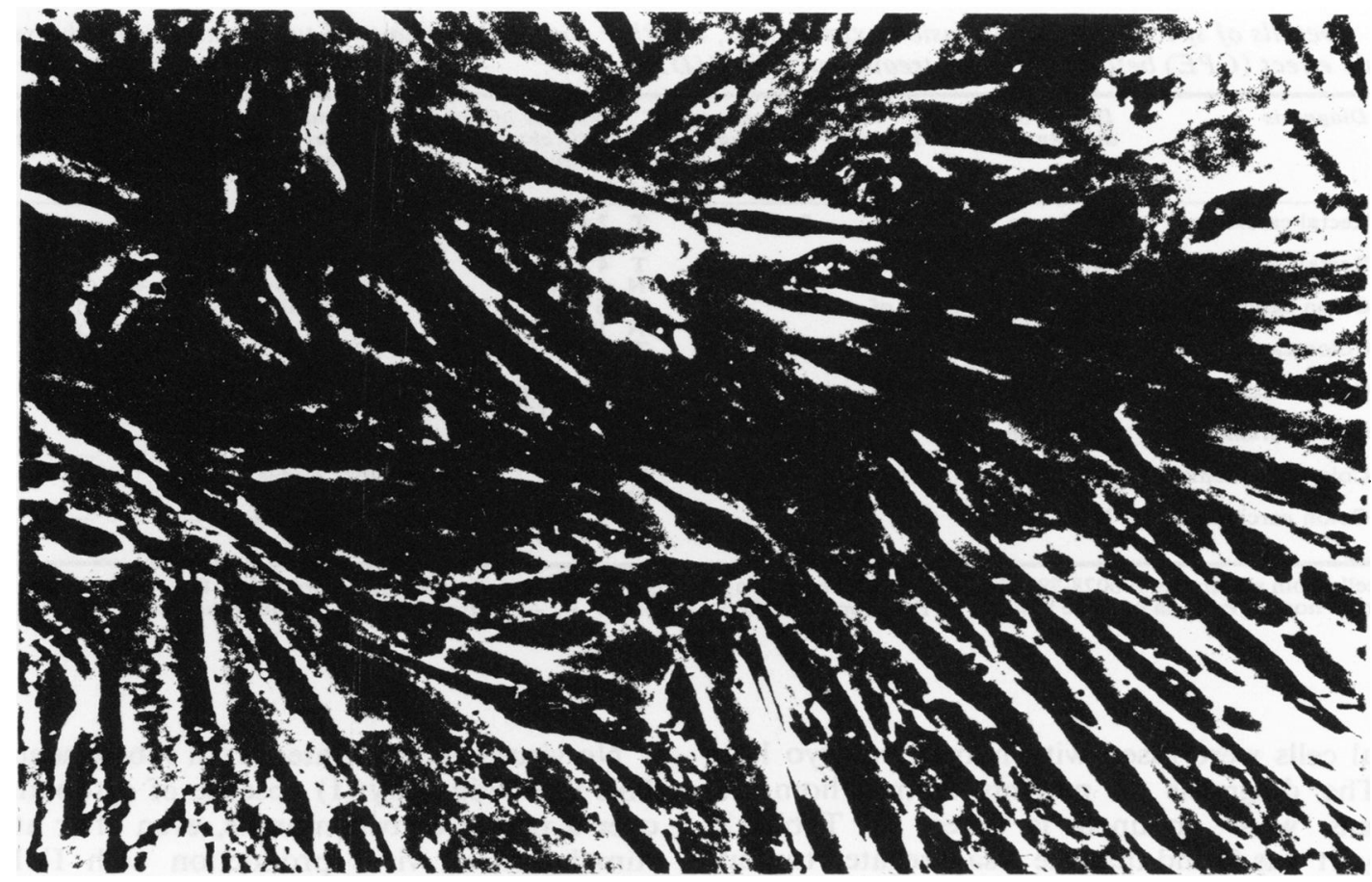

Fig. 4 Fibroblastic cells obtained on culture of colonic adenocarcinoma specimen. $x$ 825, phase contrast.

two-weekly intervals for periods of up to four months. In one case, a mixture of fibroblasts and epithelial cells was obtained.

All cultures were observed microscopically every week, and at no time was a cytopathic effect apparent.

In addition to culturing cells from tumour specimens, pieces of normal intestinal mucosa from the same patient were used. All 17 cultures set up from this source grew as fibroblasts, identical with those fibroblastic cells obtained from the seven adenocarcinomas described above. Again, no cytopathic effect was apparent over a three month period of observation.

A summary is given in Table 1 of the types of cells which were obtained on culture from the carcinoma specimens, together with the degree of differentiation of the tumour and the Dukes's stage.

Table 1 Details of cell type obtained on culture of colonic or rectal carcinomas, degree of differentiation of tumour, and Dukes's stage

\begin{tabular}{|c|c|c|c|c|c|c|}
\hline \multirow{2}{*}{$\begin{array}{l}\text { Degree of } \\
\text { differentiation }\end{array}$} & \multicolumn{3}{|c|}{ Dukes's stage $B$} & \multicolumn{3}{|c|}{ Dukes's stage $C$} \\
\hline & Well & Moderate & Poor & Well & Moderate & Poor \\
\hline $\begin{array}{l}\text { Cell type: } \\
\text { Fibroblastic } \\
\text { Epithelial } \\
\text { Bipolar } \\
\text { No growth }\end{array}$ & $\begin{array}{l}0 \\
0 \\
2 \\
0\end{array}$ & $\begin{array}{l}1 \\
4 \\
1 \\
7\end{array}$ & $\begin{array}{l}2 \\
0 \\
0 \\
6\end{array}$ & $\begin{array}{l}1 \\
1 \\
0 \\
0\end{array}$ & $\begin{array}{l}1 \\
2 \\
2 \\
2\end{array}$ & $\begin{array}{l}2 \\
0 \\
1 \\
1\end{array}$ \\
\hline
\end{tabular}

CO-CULTIVATION

Equal numbers of viable cells from adenocarcinoma of the colon or rectum and cells from pieces of normal colon were mixed with human embryo lung cells and used to seed Falcon flasks. Specimens from six patients were used, three of Dukes's stage $\mathrm{B} \stackrel{+}{-\frac{+}{\sigma}}$ moderately differentiated, one of stage $B$ poorly $\underline{3}$. differentiated, one of stage $C$ well differentiated, and $\grave{\delta}$ one of stage $\mathrm{C}$ moderately differentiaıed.

Initially, there was a cytotoxic effect on the human embryo lung cells, so that, after two or three days in culture, some were detached and others more 을. rounded and granular than normal. The ones which $\bar{N}$ survived gradually grew out into monolayers, this $\sigma$ taking about a month. Some colonic cells with a different morphology from human embryo lung cells $\omega$ persisted over this time also. The cultures were split at about monthly intervals and observed microscopically over two to three months for cytopathic effect. None was seen, although sometimes the cells looked granular and did not grow as quickly as normal. Labelling of the cultures with ${ }^{3} \mathrm{H}$-thymidine $\mathbb{\mathbb { D }}$ followed by sucrose density gradient centrifugation $\frac{\odot}{\mathbb{D}}$ of the concentrated culture supernatant did not reveal radioactive material with the density of cytomegalovirus .

FUSION

Paired samples of fresh tumour and normal colonic $\stackrel{\frac{\vec{O}}{P}}{P}$ 
Table 2 Details of specimens used in fusion experiments, together with viable counts of tumour cells and observations of cytopathic effect (CPE) before and after treatment with IUDR

\begin{tabular}{|c|c|c|c|c|c|c|c|}
\hline Number & Diagnosis & $\begin{array}{l}\text { Degree of } \\
\text { differentiation of tumour }\end{array}$ & $\begin{array}{l}\text { Dukes's stage } \\
\text { of carcinoma }\end{array}$ & $\begin{array}{l}\text { Number of viable } \\
\text { cells obtained } \\
\text { for fusion }\end{array}$ & $\begin{array}{l}\text { Comments on } \\
\text { tumour cell } \\
\text { suspension } \\
\text { before fusion }\end{array}$ & $C P E$ & $\begin{array}{l}C P E \text { after } \\
I U D R \text { treatment }\end{array}$ \\
\hline 790004 & Rectal carcinoma & Moderate & B & \multirow{8}{*}{$\begin{array}{l}2 \times 10^{6} \\
2 \times 10^{6} \\
4 \times 10^{6} \\
4 \times 10^{5} \\
6 \times 10^{6} \\
10^{6} \\
2.5 \times 10^{5} \\
10^{6} \\
2 \cdot 4 \times 10^{5} \\
1.5 \times 10^{6} \\
2 \times 10^{6} \\
4 \times 10^{6} \\
10^{6} \\
10^{6} \\
5 \times 10^{5} \\
2 \times 10^{6}\end{array}$} & \multirow{3}{*}{$\begin{array}{l}20 \% \text { viable } \\
\text { Large numbers } \\
\text { of polymorphs } \\
10 \% \text { viable }\end{array}$} & \multirow{3}{*}{$\begin{array}{l}- \\
\bar{t}+ \\
+++ \\
+++\end{array}$} & \multirow{3}{*}{$\begin{array}{l}- \\
0 \\
0 \\
0 \\
0\end{array}$} \\
\hline & Rectal carcinoma & Moderate & B & & & & \\
\hline 790021 & Colon carcinoma & $\begin{array}{l}\text { Moderate with foci of } \\
\text { poorer differentiation }\end{array}$ & B & & & & \\
\hline 790028 & Colon carcinoma & Moderate & B & & $\begin{array}{l}80 \% \text { viable } \\
\text { clumps }\end{array}$ & - & $\underline{-}$ \\
\hline 790043 & Colon carcinoma & Moderate & $\mathbf{A}$ & & $\begin{array}{l}80 \% \text { viable } \\
\text { clumps }\end{array}$ & & - \\
\hline 790046 & Colon carcinoma & Moderate & B & & $80 \%$ viable & - & - \\
\hline 790083 & Colon carcinoma & Moderate & B & & $90 \%$ viable & $\bar{z}$ & $\overline{-}$ \\
\hline 790088 & Colon carcinoma & Poor & C & & $90 \%$ viable & - & - \\
\hline
\end{tabular}

Tumour cells from specimens $790028-790088$ were pırified by gravity sedimentation through fetal calf serum before fusion. $T$ : cells from tumour. $\mathrm{N}$ : cells from normal mucosa of same patient. CPE: cytopathic effect.,,$++++++:$ degrees of CPE. - : negative result. $\bigcirc:$ not done or not
tested.

mucosal cells were fused with human embryo lung cells. The diagnosis of patients from whom the specimens were obtained is given in Table 2 . Initially, it was found that the disaggregated tumour contained a mixture of cells whose viability ranged from $10-20 \%$. Gravity sedimentation through a layer of fetal calf serum increased the purity and number of viable cell clumps to $80-90 \%$ and these were used latterly for the fusion (Table 2). The cultures of fused cells were observed for periods of two months. On two separate occasions a cytopathic effect was observed in the heterokaryons from two patients - namely, 790020 and 790021 - five and six weeks respectively after the fusion.

These isolates proved to be cytomegalovirus by anti-complement immunofluorescence and by labelling with ${ }^{3} \mathrm{H}$-thymidine, followed by sucrose density gradient centrifugation, which revealed particles of the same density as that of cytomegalovirus.

They were further analysed by restriction endonuclease cleavage of the viral DNA. The fragments produced showed complete identity with AD-169 strain of cytomegalovirus (Fig. 5). The virus labelled 790021T had an extra band of high molecular weight which was thought to represent incomplete digestion rather than any real difference in the pattern. Strain AD-169 was being used in the laboratory at the same time as these cultures. Great care, including the use of a separate room, was taken to handle the clinical specimens away from this virus, but it had to be assumed that contamination had occurred on these two occasions, as it is hardly possible that both 'strains isolated should have the characteristics of AD-169.
No viruses were isolated from subsequent fusions. This was judged by (1) absence of cytopathic effect over a period of two months, even after attempted stimulation of virus production with IUDR; (2) labelling with ${ }^{3} \mathrm{H}$-thymidine two months after the fusion to ensure that the absence of cytopathic effect also meant the absence of productive viral infection; and (3) anti-complement immunofluorescence which was negative on both the unstimulated and IUDRstimulated heterokaryons using three specially selected high titre sera with antibodies to cytomegalovirus early and late antigens.

In addition to the fusion attempts with freshly isolated tumour cells, the two adenocarcinoma cell lines were fused with human embryo lung cells. No virus was rescued from these even after IUDR treatment. Also both the original colonic lines and their heterokaryons did not express the cytomegalovirus early or late antigens as tested by anticomplement immunofluorescence.

\section{IN SITU HYBRIDISATION}

The patients from whom the specimens were obtained for in situ hybridisation are shown in Table 3 along with the pathological diagnosis. In each case a piece of tumour was used to make frozen sections and also a piece of normal intestine away from the site of the tumour. These sections, were subjected to in situ hybridisation to assay for cytomegalovirus mRNA within the cells using ${ }^{3} \mathrm{H}$-labelled DNA of cytomegalovirus as a probe. As a positive control, human embryo lung cells were infected with cytomegalovirus and fixed two days after infection. When developed, after hybridisation and autoradiography, the infected cells showed an average of over 100 


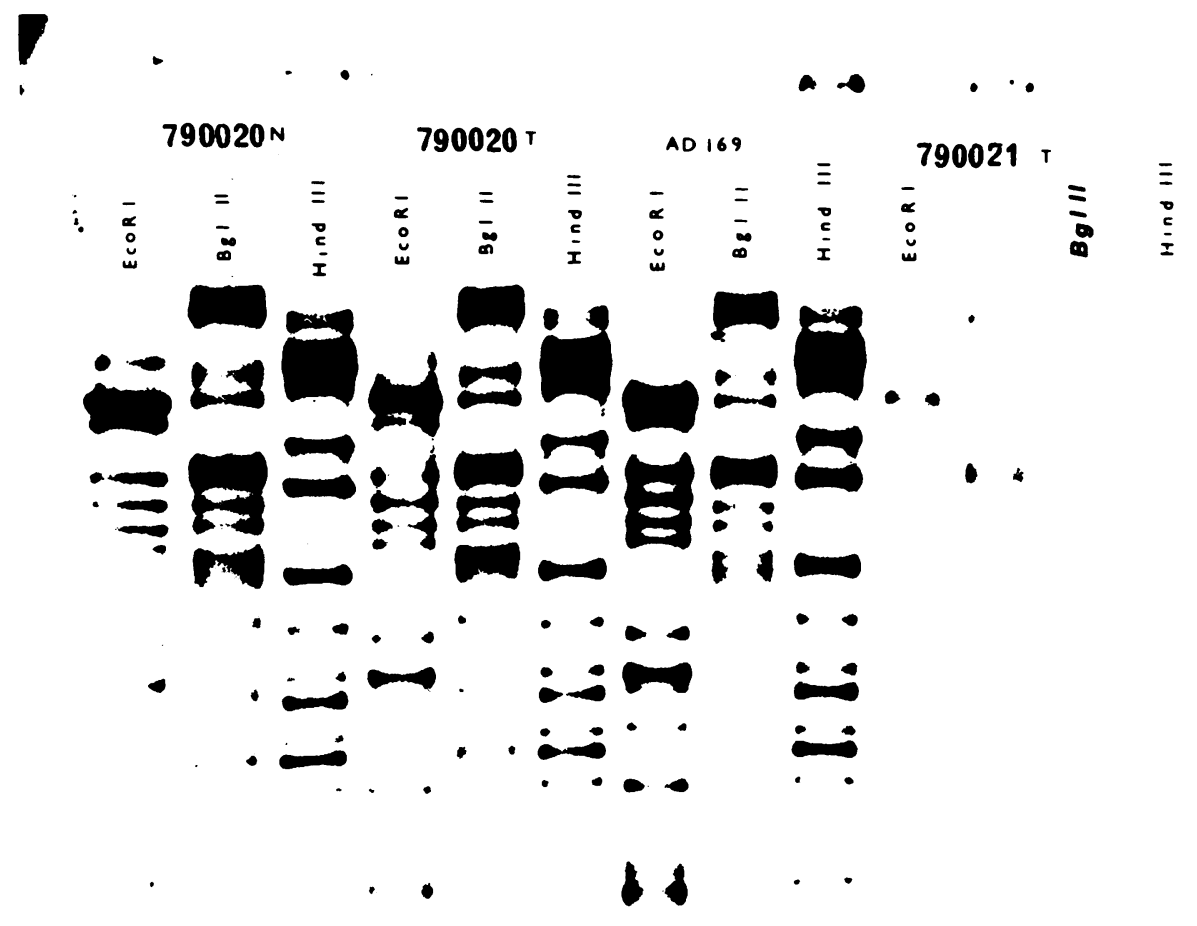

Fig. 5 Restriction endonuclease patterns of DNA from cytomegalovirus strain AD-169, and cytomegalovirus passaged in heterokaryons of human embryo lung cells fused with normal $(N)$ and tumour $(T)$ colonic cells of patient 790020 , and tumour $(T)$ colonic cells of patient 790021. The viral DNA was digested with EcoRI, BglII, and HindIII endonucleases.

Table 3 Specimens used for in situ hybridisation with $C M V^{3} H-D N A$ as probe, and for amplified direct immunofluorescence with human CMV antisera

\begin{tabular}{|c|c|c|c|c|c|c|}
\hline Number & Diagnosis & Sex, age $(y r)$ & Dukes's stage & $\begin{array}{l}\text { Degree of } \\
\text { differentiation }\end{array}$ & $\begin{array}{l}\text { In situ } \\
\text { hybridisation }\end{array}$ & $\begin{array}{l}\text { Immuno- } \\
\text { fluorescence }\end{array}$ \\
\hline $\begin{array}{l}790020 \\
790082 \\
790083 \\
790084 \\
790111 \\
790112 \\
80037 \\
80045 \\
80046 \\
80054 \\
80055 \\
80067 \\
80084 \\
80085 \\
80105 \\
80106\end{array}$ & $\begin{array}{l}\text { Rectal adenocarcinoma } \\
\text { Diverticular disease } \\
\text { Colonic adenocarcinoma } \\
\text { Colonic adenocarcinoma } \\
\text { Colonic adenocarcinoma } \\
\text { Colonic adenocarcinoma } \\
\text { Caecal adenocarcinoma } \\
\text { Colonic adenocarcinoma } \\
\text { Rectal adenocarcinoma } \\
\text { Caecal adenocarcinoma } \\
\text { Caecal adenocarcinoma } \\
\text { Colonic adenocarcinoma } \\
\text { Caecal adenocarcinoma } \\
\text { Caecal adenocarcinoma } \\
\text { Caecal adenocarcinoma } \\
\text { Colonic adenocarcinoma }\end{array}$ & $\begin{array}{ll}\text { F } & 57 \\
\text { F } & 70 \\
\text { F } & 84 \\
\text { F } & 74 \\
\text { F } & 73 \\
M & 57 \\
M & 50 \\
\text { F } & 83 \\
M & 76 \\
\text { M } & 75 \\
\text { F } & 69 \\
M & 59 \\
F & 63 \\
\text { F } & 81 \\
M & 75 \\
\text { F } & 79\end{array}$ & $\begin{array}{l}\text { B } \\
\text { B } \\
\text { C } \\
\text { C } \\
\text { C } \\
\text { B } \\
\text { C } \\
\text { B } \\
\mathbf{B} \\
\mathbf{C} \\
\mathbf{B} \\
\mathbf{B} \\
\mathbf{C} \\
\mathbf{C}\end{array}$ & $\begin{array}{l}\text { Moderate } \\
\text { Moderate } \\
\text { Poor } \\
\text { Moderate } \\
\text { Poor } \\
\text { Poor } \\
\text { Moderate } \\
\text { Moderate } \\
\text { Well } \\
\text { Moderate } \\
\text { Poor } \\
\text { Moderate } \\
\text { Poor } \\
\text { Poor } \\
\text { Moderate }\end{array}$ & $\begin{array}{l}\text { Negative } \\
\text { Negative } \\
\text { Negative } \\
\text { Negative } \\
\text { Negative } \\
\text { Negative } \\
\text { Negative } \\
\text { Negative } \\
\text { Negative } \\
\text { Negative } \\
\text { Negative } \\
\text { Negative } \\
\text { Negative } \\
\text { Negative } \\
\text { Not done } \\
\text { Not done }\end{array}$ & $\begin{array}{l}\text { Not done } \\
\text { Not done } \\
\text { Negative } \\
\text { Negative } \\
\text { Not done } \\
\text { Not done } \\
\text { Negative } \\
\text { Negative } \\
\text { Negative } \\
\text { Not done } \\
\text { Negative } \\
\text { Negative } \\
\text { Not done } \\
\text { Not done } \\
\text { Negative } \\
\text { Negative }\end{array}$ \\
\hline
\end{tabular}


grains per cell, while the uninfected cells had less than 2 grains per cell.

For the frozen sections, both of tumour and normal tissue, in no case was any cell seen in which there were more than 2 grains, and all were concluded to be negative.

\section{IMMUNOFLUORESCENCE}

The technique of AMDI was used to examine the sections of human tissue for cytomegalovirus antigens as the background staining obtained by ACIF and indirect immunofluorescence was unacceptable. This might be due to complement receptors, ${ }^{21}$ or to antibody-antigen complexes present on the surface of the mucosal epithelial cells. In common with many other groups, attempts to produce animal sera with sufficient amounts of antibody to early antigens were not successful. When AMDI was used on human embryo lung cells infected with cytomegalovirus, the pattern of immunofluorescence appeared as a uniform staining of nuclear antigens (Fig. 6).

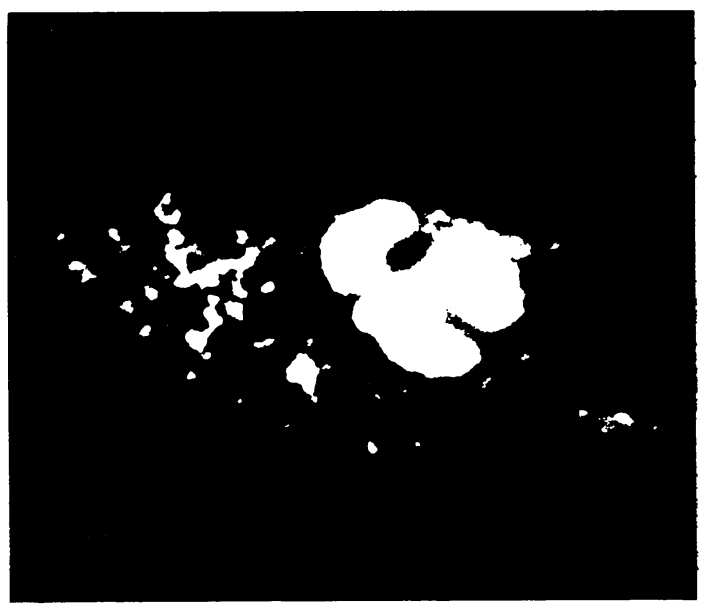

Fig. 6 AD-169 infected human embryo lung cells (early antig(n) strained by amplified direct immunofluorescence (AMDI) showing a uniform staining of nuclear antigens.

Frozen sections from nine paired specimens of adenocarcinoma and normal gut mucosa were screened by AMDI as shown in Table 3 and all were negative. Occasionally, immunofluorescence was seen in the normal mucosa adjacent to the tumour. This seemed to be due to the cross-reactivity of batches of FITC anti-rabbit IgG with human IgG, and could be eliminated by selecting non-crossreactive conjugates.

\section{Discussion}

Cytomegalovirus has been isolated from several cases of adenocarcinoma of the colon by long-term culture of the tumour tissue." The cells which grew out were fibroblastic in appearance with less than $1 \%$ being epithelial, these being lost on subculture. Cytomegalovirus was not apparent until several weeks after initiation of the culture. In the work reported here, long-term cultures of adenocarcinoma tissues did not yield cytomegalovirus on any occasion. The cells which grew were sometimes fibroblastic, although a medium containing D-valine was used in an attempt to inhibit these. ${ }^{\times}$Small areas containing tightly packed epithelial cells were seen in about $30^{\circ}$, of the cultures a few days after the initiation; these were subsequently lost on subculture.

As cells containing cytomegalovirus might not be the ones which survived and grew in culture, we also used the techniques of co-cultivation and fusion with cells permissive for cytomegalovirus replication. It has been shown in several systems that, if a whole viral genome is present in a transformed cell, it can be rescued in this way. One example is the lymphoblastoid Raji cell line which contains 50-60 copies of Epstein Barr virus DNA but does not produce infectious virions unless fused with D-98 (a derivative of HeLa cells) and induced with IUDR. ${ }^{22}$

Of the Herpes viruses, the transforming ability of cytomegalovirus is least well known, although it has been shown to have the potential to transform in several in vitro systems ${ }^{23-25}$. However, the low numbers of successful examples of such transformations might indicate that an event of tumour promotion is required in addition to the initial viral stimulation of cell DNA. ${ }^{26}$ It is possible, for example, that human cytomegalovirus could be responsible for transformation of the mucosal cells of the epithelial lining of the large bowel and that this process is promoted by dietary factors or bile salts. Transformation by cytomegalovirus of epithelial cells has not been reported in vitro. The virus seems to undergo a low semi-permissive type of replication in human epithelial amnion cells, ${ }^{27}$ human lung epithelial cells, ${ }^{2 x}$ and human ecto- and endocervical cells. ${ }^{39}$

Both co-cultivation and fusion experiments did not yield infectious cytomegalovirus even after prolonged culture. In addition, treatment with IUDR, which has been shown to be necessary for activation of cytomegalovirus from a latent state in heterokaryons of non-permissive cells, ${ }^{7}$ did not induce any virus. On two occasions accidental contamination with AD-169 strain of cytomegalovirus occurred, despite great care being taken in the 
handling of these long-term cultures. It was of interest, however, that the fragments produced by restriction endonuclease cleavage of viral DNA were identical for the virus grown in human embryo lung cells and that passaged in the adenocarcinoma tumour cell-human embryo cell heterokaryons. This does not suggest a recombination with other cytomegalovirus genetic material which might be present in the colonic cells.

Of course, it is possible that either the whole genome is not present in the adenocarcinoma cells or that it cannot be rescued by such culture methods. The latter is true of another transforming virus, Adeno type 12, which recently has been shown to induce rat brain tumors in vivo and to integrate the entire viral genome in the host cell. However, no infectious virus could be obtained from subsequent fusions or co-cultivations of the tumour cells with permissive cells. ${ }^{30}$

Therefore, two more direct approaches were used during this work-firstly, AMDI to detect cytomegalovirus antigens on frozen sections of adenocarcinoma and normal intestinal specimens, and secondly in situ hybridisation to detect cytomegalovirus mRNA.

Looking for viral antigens by an AMDI test has proved a good approach where the availability of specific animal antiviral serum is limited by the restriction of viral replication to human cells, as is the case with cytomegalovirus. Until a mixture of monclonal antibodies detecting a range of early and late cytomegalovirus antigens is available, antibodypositive human sera are the least cross-reactive reagents with human biopsies. No immunofluorescence was found using the two human sera selected, although they contained antibodies to early and late cytomegalovirus antigens, and thus no cytomegalovirus antigens were shown to be present in the tumour or normal intestinal cells.

In situ hybridisation has proved a useful technique in many systems to search for the presence of viral nucleic acids in cells where there is no productive infection-for example, it has been used to detect Herpes simplex type 2 mRNA in sections prepared from frozen biopsies of patients with cervical dysplasia. $^{31}$ This method has the considerable advantage of picking out perhaps only one or two cells in the section which might contain viral $\mathrm{mRN}$ and, in addition, there should be amplification of any viral information by assaying the mRNA rather than DNA. No hybridisation was found in the intestinal tumour or normal sections with cytomegalovirus ${ }^{3} \mathrm{H}$-DNA as probe. Huang and Roche used another hybridisation technique - that of membrane cRNA-DNA hybridisation, which detects viral DNA extracted from the tumour specimens-and found that more than $50 \%$ of patients with adenocarcinoma of the colon had greater than 2 genome equivalents of $\mathrm{CMV} /$ cell. $^{1}$ However, vely recently, this work has not been corroborated using a DNA-DNA reassociation kinetics test which had an estimated sensitivity of 0.3 genomes equivalents per cell. No cytomegalovirus DNA was detected in biopsy specimens from seven patients with adenocarcinoma of the colon. ${ }^{32}$ Such a method has given positive results in examining tumour cells of patients with Kaposi's sarcoma cytomegalovirus genomes. ${ }^{33}$ Thus, there is considerable doubt as to whether the colonic adenocarcinoma cells contain any cytomegalovirus DNA, although it may not be possible to detect a smaller $(<0.3$ genome equivalents) fragment of viral DNA. However, a smaller fragment amplified as mRNA or specific viral protein could be detected by in situ hybridisation and AMDI immunofluorescence.

We conclude, therefore, that cytomegalovirus is unlikely to contribute to the maintenance of the transformed phenotype of the adenocarcinoma cells and that there is no localised cytomegalovirus reactivation contiguous to the tumour, a situation observed in metastatic nasopharyngeal carcinoma. ${ }^{34}$

We wish to thank Mr I McLeod and his theatre staff at the Royal Infirmary of Edinburgh for their very helpful co-operation in this work. Also we are grateful to Dr H Gilmour for drawing up the case histories of patients and for doing the histological examination of specimens. We thank $\mathrm{Dr}$ E-S Huang for showing Dr $\mathrm{H}$ Hart the technique of restriction endonuclease analysis of cytomegalovirus in his laboratory in Chapel Hill, North Carolina. Grant support for this work was given by the Cancer Research Campaign.

\section{References}

${ }^{1}$ Huang ES, Roche JK. Cytomegalovirus DNA and adenocarcinoma of the colon: evidence for latent viral infection. Lancet 1978; 1:957-60.

${ }^{2}$ Hashiro GM, Horikami S, Loh PC, Cytomegalovirus isolations from cell cultures of human adenocarcinoma of the colon. Intervirology 1979; 12:84-8.

${ }^{3}$ Henson D. Cytomegalovirus inclusion bodies in gastrointestinal tract. Arch Pathol 1972; 93:477-82.

${ }^{4}$ Farmer $\mathrm{GW}$, et al. Viral investigations in ulcerative colitis and regional enteritis. Gastroenterology 1973; 65:8-18.

${ }^{5}$ Sidi S, Graham JH, Razvi SA, Banks PA. Cytomegalovirus infection of the colon associated with ulcerative colitis. Arch Surg 1979; 114:857-9.

${ }^{6}$ Phillpotts RJ, Hermon-Taylor J, Teich NM, Brooke BN. A search for persistent virus infection in Crohn's disease. Gut 1980;21:202-7. 
'Boldogh I, Gonczol E, Gartner L, Vaczi G. Expression of the human cytomegalovirus genome in mouse cells and in human-mouse heterokaryons. Arch Virol $1977 ; 53: 101-8$.

${ }^{8}$ Gilbert SF, Migeon BR. D-valine as a selective agent for normal human and rodent epithelial cells in culture. Cell 1975; 5:11-17.

${ }^{\circ}$ Courtenay VD, Mills J. An in vitro colony assay for human tumors grown in immuno-suppressed mice and treated in vivo with cytotoxic agents. Br J Cancer 1978; 37:261-8.

${ }^{10}$ Semple TU, Quinn LA, Woods LK, Moore GE. Tumour and lymphoid cell lines from a patient with carcinoma of the colon for a cytotoxicity model. Cancer Res 1978; 38:1345-55.

${ }^{11}$ Pontecorvo M. Production of mammalian somatic-cell hybrids by means of polyethylene glycol treatment. Somatic Cell Genet 1975; 1:379-400.

${ }^{12}$ Norval M, Hart H, Marmion BP. Viruses and lymphocytes in rheumatoid arthritis. I. Studies on cultured rheumatoid lymphocytes. Ann Rheum Dis 1979; 38: 507-13.

${ }^{13}$ Norval M, Marmion BP. Attempts to identify viruses in rheumatoid synovial cells. Ann Rheum Dis 1976; 35:106-113.

${ }^{14}$ Kettering JD, Schmidt NS, Gallo D, Lennette EH. Anti-complement immunofluorescence test for antibodies to human cytomegalovirus. J Clin Microbiol $1977 ; 6: 627-32$.

${ }^{15}$ Kilpatrick BA, Huang E-S, Pagano JS, Analysis of cytomegalovirus genomes with restriction endonucleases Hind III and EcoR-1.J Virol 1976; 18:1095-105.

${ }^{16}$ Huang E-S, Chen S-T, Pagano JS. Human cytomegalovirus. I. Purification and characterization of viral DNA. J Virol 1973; 12:1473-81.

${ }^{17}$ Rigby PW, Dieckmann M, Rhodes C, Berg P. Labelling deoxyribonucleic acid to a high specific activity in vitro by nick translation with DNA polymerase $I$. J Mol Biol 1977; 113:237-251.

${ }^{18}$ Schmitz H, Kampa D. Amplified direct immunofluorescence (AMDI) for detection of Epstein-Barr virus nuclear antigen. J Immunol Meth 1979;26:173-86.

${ }^{19}$ Nairn RC. Appendix. In: Nairn RC, ed. Fluorescent protein tracing. Edinburgh: Churchill Livingstone, 1976; 369-75.

${ }^{20}$ Leibovitz A, Stinson JC, McCombs WB, McCoy CE, Mazur KC, Mabry N. Classification of human colorectal adenocarcinoma cell lines. Cancer Res 1976; 36:4562-9.

${ }^{21}$ Lay WH, Nussenzweig V. Receptors for complement on leucocytes. J Exp Med 1968; 128:991-1009.

${ }^{22}$ Glaser R, Nonoyama M. Host cell regulation of induction of Epstein-Barr virus. J Virol 1974; 14: 174-6.

${ }^{23}$ Albrecht T, Rapp F. Malignant transformation of hamster embryo fibroblasts following exposure to ultraviolet-irradiated human cytomegalovirus. Virology 1973; 55:53-61.

${ }^{24}$ Geder L, Kreider J, Rapp F. Human cells transformed in vitro by human cytomegalovirus: tumorigenicity in athymic nude mice. J Natl Cancer Inst 1977; 58: 1033-9.

${ }^{25}$ Boldogh I, Gonczol E, Vaczi L. Oncogenic transformation of hamster embryonic fibroblast cells by UV-irradiated human cytomegalovirus. Acta Microbiol Acad Sci Hung 1978; 25:269-75.

${ }^{26} \mathrm{Li} \mathrm{JL}$, Albrecht $\mathrm{T}$. Acquisition of a transformed phenotype by human embryo lung cells persistently infected with human cytomegalovirus following exposure to 4-nitroquinoline-1-oxide (NQO). Abstr Ann Meet Am Soc Microbiol 1979; 301. S(H)46.

${ }^{27}$ Figueroa ME, Geder L, Rapp F. Infection of human amnion cells with cytomegalovirus. J Med Virol 1978; 2:369-75.

${ }^{28}$ Michelson-Fiske S, Arnoult J, Febvre H. Cytomegalovirus infection of human lung epithelial cells in vitro. Intervirology 1975; 5:354-63.

${ }^{29}$ Vesterinen E, Leinikki P, Saksela E. Cytopathogenicity of cytomegalovirus to human ectocervical and endocervical epithelial-cells in vitro. Acta Cytol 1975; 19:473-81.

${ }^{30}$ Ibelgaufts $\mathrm{H}$, Doerfler W, Scheidtmann KH, Wechsler W. Adenovirus type 12-induced rat tumour cells of neuroepithelial origin: persistence and expression of the viral genome. J Virol 1980; 33:423-37.

${ }^{34}$ McDougall JK, Galloway DA, Fenoglio CM. Cervical carcinoma: detection of Herpes simplex virus RNA in cells undergoing neoplastic change. Int J Cancer 1980; 25:1-8.

${ }^{32}$ Brichacek B, Hirsch I, Zavadova H, Prochazka M, Faltyn J, Vonka V. Absence of cytomegalovirus DNA from adenocarcinoma of the colon. Intervirology 1980;14:223-7.

${ }^{33}$ Giraldo G, Beth E, Huang E-S. Kaposi's sarcoma and its relationship to cytomegalovirus (CMV). III. CMV DNA and CMV early antigens in Kaposi's sarcoma. Int J Cancer 1980; 26:23-9.

${ }^{34}$ Soffer D, Horoupian DS. Localised cytomegalovirus encephalitis contiguous to metastatic nasopharyngeal carcinoma. Arch Pathol Lab Med 1979; 103:355-8. 